\title{
Integrating Gender Analysis into Socio-Economic Needs Assessment in Afghanistan
}

\section{Dr Deniz Kandiyoti}

School of Oriental and African Studies

University of London
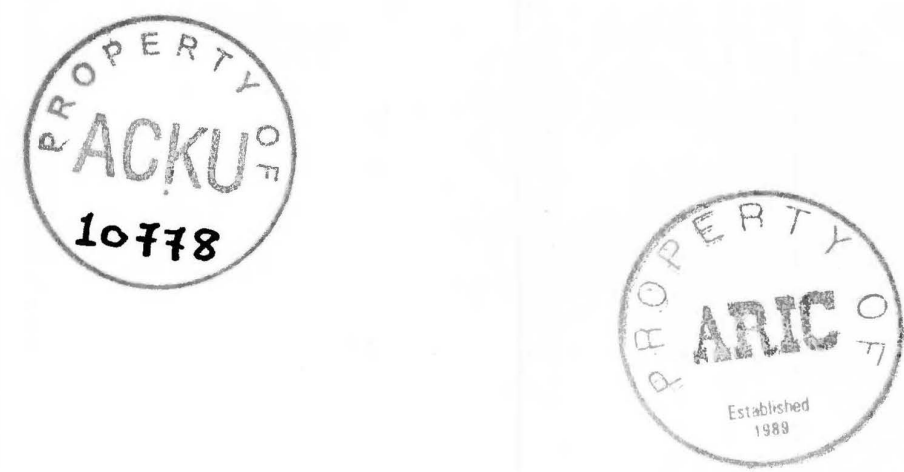


\title{
UNIFEM
}

\section{Integrating Gender Analysis into Socio-economic Needs Assessment in Afghanistan}

\author{
Deniz Kandiyoti
}

\section{The Aim of the Study}

As the UN agency with a unique mandate to provide financial and technical assistance to innovative programmes and strategies that promote women's human rights, political participation and economic security, UNIFEM's strategy in Afghanistan has focused on supporting women's participation in reconstruction and peace building. This strategy has included assisting with capacity building at the governmental and non-governmental levels (working with MOWA to mainstream gender into the work of other Ministries, establishing regional Women's Centres to train local NGOs), supporting women's leadership roles at community and national levels, strengthening women's economic security (especially for vulnerable groups) and combating violence against women.

The value of a rights-based approach advocating an expansion of women's civic and political participation under legal guarantees and a framework of enhanced security is incontestable. However, the long term goals of Afghan reconstruction and the eventual shift from humanitarian assistance to more developmental objectives require a thorough understanding of evolving livelihoods contexts in urban and rural Afghanistan. These contexts condition both the opportunities and the constraints that women and girls (alongside men and boys) experience in their daily lives. The constraints faced by women and girls have both short and long-term consequences for their ability to avail themselves of the potential benefits of any expansion of their formal rights or their increased access to services (such as health and education). Policies aimed at expanding Afghan women's entitlements and capabilities must necessarily take account of the socio-economic contexts in which their productive, reproductive and communal activities are embedded.

The principal aim of this study is to complement rights-based approaches to women's empowerment with gender analysis of livelihood systems in the context of Afghan reconstruction. Although it is widely recognized that over two decades of conflict have produced long-term consequences for the political economy of the country, exposing livelihoods at the local level to multiple sources of vulnerability, the gender effects of these transformations are, as yet, poorly understood. ${ }^{1}$ One of the central premises of the study is that programmes and policies aimed at women's economic and political empowerment must necessarily be based upon a properly contextualized understanding of the operations of gender within domestic units and in communities across different regions of Afghanistan. ${ }^{2}$ The nature of interdependencies between genders and

\footnotetext{
${ }^{1}$ The term 'gender' is used to denote the whole ensemble of relationships between men and women, the young and the old.

${ }^{2}$ Clarke and Seeman (1998) illustrate the diversity of regional economies in Afghanistan and Pain (2002)
} 
generations, the types of dislocation and readjustment occasioned by processes of displacement, loss and dispossession and the creation of new areas of uncertainty and vulnerability (for men, women, the young and the elderly) must receive detailed attention as the basis for informed policy. UNIFEM with its long track record of expertise in gender issues is uniquely placed to provide technical guidance and tools for gender analysis to assist with gender mainstreaming in the UN system, in bilateral and multilateral donor projects, in the various ministries of the ATA, and the international and local NGOs.

\section{$\underline{\text { Structure of the Report }}$}

The report is presented in three parts. Part 1 provides a brief overview of our current resources for the study of women and gender in Afghanistan and identifies the most significant gaps in our knowledge.

Part 2 proposes a more holistic approach based on the analysis of changing livelihoods and household formation practices in Afghanistan. It is suggested that gender analysis is not peripheral to understanding livelihoods but central to it. This contention is illustrated with reference to case studies drawn from the literature and from data obtained during the pilot stage of the UNIFEM study. ${ }^{3}$

Part 3 presents the methodology and time frame of the UNIFEM study. The study is set in the context of broader efforts in the field of livelihoods enhancement and monitoring in Afghanistan.

\section{Part 1: Women and Gender in Afghanistan : Identifying the Gaps}

It is possible to identify three major gaps in our current resources for the study of women and gender in Afghanistan.

The first has to do with our relatively thin knowledge base. The history of conflict of over two decades has denied scholarly access to the field to both local and foreign researchers. As a result, there are few fieldwork based attempts to come to grips with gender relations in Afghanistan (such as Tapper 1991, Grima, 1992 and more recently Pont, 2001).

Most work undertaken in the ' $80 \mathrm{~s}$ and ' $90 \mathrm{~s}$ has been conducted in refugee contexts rather than in Afghanistan per se (Christensen, 1984, 1988, 2000, Howard-Merriam, 1987, Azberbaijani-Moghadam, 2001). Most publications and reports (including a recent ILO study by Barakat and Wardell, 2001) tend to rely on compilations of secondary material rather than on primary data.

\footnotetext{
makes a cogent case for taking these diversities into account.

${ }^{3}$ The pilot stage took place between September-November 2002 and is based on fieldwork carried out in Parwan and Kandahar provinces. Thanks are due to Christine Lamoureux and Najia Zewari for their contributions during this phase.
} 
Many works focus on the impact of successive regimes in Afghanistan, from King Amanullah's modernizing reforms to the Taliban, on the life options and mobility of women. (Dupree, 1994, 1998; Centlivres-Demont, 1994, Moghadam, 2002, Marsden, 1999). These provide important chronicles of the ups and downs of Afghan political life and an account of the manner in which women were buffeted by cross-currents using them as symbols of modernity or of Islamic propriety. ${ }^{4}$

There are intrinsic limitations, however, to approaches that foreground state policies in a context where it is widely recognized that the state's interface with the local communities that form the bedrock of Afghan society was limited, whether in terms of the legal framework, revenue collection or service delivery (Roy 1985, Rubin 1995, 1996, Wimmer and Schetter, 2002, Byrd, 2002, Cramer and Goodhand , 2002). ${ }^{5}$ These limitations are even more apparent in the domain of kinship and gender relations where the penetrative capacity of states come up against significant obstacles even in cases where nation-building projects have been more robust (Kandiyoti, 1991).

Despite these provisos, the severity of the measures adopted by the Taliban in their search for an Islamic order has kept the spotlight on women's loss of basic rights in Afghanistan. Few issues have aroused as many passions as the plight of Afghan women under the rule of the Taliban. ${ }^{6}$ It is not surprising that most efforts in the post-Taliban period have concentrated on stock-taking and on proposals to support women's full participation in Afghan reconstruction and the maintenance of peace and security (Human Rights Watch 2001, 2002, WOMANKIND Worldwide, 2002, Benjamin 2002, Brunet and Solon Helal, 2002).

Rights-based approaches are central to ensuring compliance with internationally recognized standards set out in the conventions and declarations of the United Nations. However, the obstacles to women's full civic and political participation can neither be explained with exclusive reference to inadequate governance structures nor to an undertheorized notion of "culture" which is often invoked to fill the gaps of our inadequate understanding. ${ }^{7}$ There is no short-cut to a historically and sociologically informed

\footnotetext{
${ }^{4}$ This is by no means unique to Afghanistan. For a broader account of the politics of gender in postcolonial states see Kandiyoti ,(1993).

${ }^{5}$ Some authors, focusing specifically on gender relations, invoke other systemic forces such as the workings of patriarchy (see for instance Moghadam, 2002, p. 20-21) or the operations of cultural complexes that go beyond Afghanistan per se (Azerbaijani-Moghadam, 2002, p.10)
}

${ }^{6}$ Despite broad agreement concerning the gross abuse of women's human rights under the Taliban, the use of Afghan women's plight on an international platform in the aftermath of Sept. $11^{\text {th }}, 2001$ elicited differing reactions in the press (for instance Vine, 2002 and Toynbee, 2002) and among academic commentators (Abu-Lughod, 2002; Moghadam ,2002; Arat-Koc, 2002).

\footnotetext{
${ }^{7}$ Non-specific recommendations concerning cultural sensitivity in matters of gender planning (see for instance Barakat and Wardell, 2001) are unhelpful unless they are backed up by time and place specific analyses that give content and substance to the assumed operations of "culture". Two types of fallacy are commonly encountered in the deployment of culture in the field of gender and development : reification (the reduction of non-homogenous and diverse patterns into essentialized and immutable categories) and
} 
analysis of the socio-economic transformations and institutional context of Afghan society as the backdrop for gender analysis.

This leads us to a second, significant gap, namely the fact that studies on general socioeconomic trends in Afghanistan tend to be gender blind. This often occurs by default rather than by design. Although there are some excellent accounts of the political economy of conflict in Afghanistan (Rubin, 2000; Pain and Goodhand, 2002; Bhatia, Goodhand, Atmar Pain and Suleman, 2002, Pain and Lautze, 2002) they fall short of drawing out the gender implications of their main conclusions due to the absence of detailed information on the functioning of the Afghan domestic economy. ${ }^{8}$ For instance, Pain and Goodhand's (2002) useful tripartite division of the Afghan economy into war, illicit and coping economies raises a number of important and, as yet, unanswered questions. In what ways have gendered divisions of labour in Afghan domestic units been affected by the war economy? How have relations between genders and generations been reconfigured in different livelihood contexts? What are the specific implications of a "masculinised" war economy for women's livelihoods and welfare? The lack of detailed analyses of the linkages between the macro-economy and livelihoods at the household level constitutes a significant gap in our understanding of the operations of gender in the Afghan context. The UNIFEM study can make a significant contribution to ongoing efforts to analyse and monitor vulnerable livelihoods in Afghanistan by incorporating gender analysis into livelihoods research.

The third and final gap relates to the area of methodology. In the absence of baseline statistics, the urgent information requirements of specialist UN agencies and NGOs needing to fulfil their mandates (in health, nutrition, literacy or other sectoral areas) or to evaluate their projects and programmes had to be filled either by single-purpose surveys or by rapid assessment and focus group techniques employing a "target group" approach. Important surveys have been carried out in the fields of maternal mortality (Physicians for Human Rights, 2002, Afghan Ministry of Health, UNICEF and CDC, 2002) and nutrition (Gardner and Mohamed, 2002), among others, providing essential pointers for policy formulation. However, these data collection techniques have the inadvertent effect of abstracting women (treated primarily as target groups with specific vulnerabilities) from the ensemble of relationships they participate in. This translates into a widespread tendency to reduce gender analysis to the study of women. This, in turn, leaves us relatively ill-equipped to understand how the Afghan domestic economy has responded to external shocks over time creating different types of vulnerability for men and women, the young and the old.

\footnotetext{
politicisation (the elevation of one version of local culture by power holders or contestants to state power into a sanctioned, official version backed up by legal and administrative dispositions). The EC Gender Guidelines which provide concrete examples of project success or failure constitute a refreshing corrective to these tendencies (Azerbaijani-Moghadam, 2002).

${ }^{8}$ It is not being suggested here that the household and the domestic economy are the only relevant institutional domain for gender analysis in Afghanistan. Far from it. However, to the extent that rightsbased approaches target extra-household institutions (the state, civil society) and governance structures this leaves a significant gap especially in Afghanistan, where women's direct involvement with markets, civil society organizations and state apparatuses is relatively limited.
} 


\section{Part 2: Towards a More Holistic Approach: Gender Analysis and Vulnerable}

\section{Livelihoods}

"When women are secure, so are nations. When women feel secure, peace is possible"

This striking statement appears in a UNIFEM report titled 'Women, War and Peace', which provides testimony to the suffering of women as victims of atrocities, internal displacement and refugee movements, of women having to shoulder the burden of maintaining and caring for their families, taking risks and demonstrating tremendous resilience and resourcefulness in the face of adversity. An important underlying assumption is that women and men experience conflict and war differently, an assumption echoed in a growing body of literature (Moser and Clark, 2001; Cockburn, 1998, Jacobs et.al., 2000). These arguments are not based on some notion of irreducible biological difference but rest upon the fact that women who find themselves in situations of conflict are already burdened with gender-specific (as well as class and ethnically conditioned) disadvantages that intensify their vulnerability. The fate -and security- of women is inextricably linked to whether or not a militarised, war economy can move to a post-conflict phase where the resumption of renewed conflict can be averted. This, in turn, partly depends on whether avenues for sustainable development offering men employment opportunities outside the war and illicit economies can materialize. ${ }^{10}$

The demographic landscape of war-torn societies with declining male populations, changing structure and composition of households and increased migration results in a sharp increase in female-headed households and a majority of women and children among the displaced in refugee camps. In countries such as Afghanistan, where a strong norm of male responsibility for the protection of women in the domestic sphere exists, these dislocations are experienced not merely as economic disasters and humanitarian tragedies but as normative and moral crises demanding regulation, sometimes through violent and ideological means. ${ }^{11}$ The erosion of normative systems and expectations under the pressure of harsh material realities (displacement, impoverishment and high levels of male mortality related to conflict) creates painful areas of uncertainty and compromise for both men and women who have to renegotiate their understanding of

\footnotetext{
${ }^{9}$ Rehn, E. and Johnson Sirleaf, E. (2002) 'Women, War and Peace. The Independent Experts' Assessment on the Impact of Armed Conflict on Women and Women's Role in Peace-building", UNIFEM. This Assessment was designed in response to UN Security Council Resolution 1325 that makes women and a gender perspective relevant to initiating and maintaining peace and reconstruction in war-torn societies.

${ }^{10}$ The missing focus on men's gendered roles in development has been critiqued by Cornwall, A (2000) and Chant and Guttman (2000).

${ }^{11}$ Povey (forthcoming) draws attention to the derogatory term Zanane bee Sarparast (unprotected women) to denote women who find themselves as heads of households, mainly as a result of becoming war widows. The inability of households to absorb and protect female kin does not absolve women of the stigma attached to being on their own and creates forms of social exclusion that deepen female poverty and vulnerability.
} 
appropriate gender roles. ${ }^{12}$ When material circumstances force men to renege on their traditionally sanctioned roles and the normative system continues to lock women into immobility and illiteracy the sphere of kinship, which is the principal arena of women's social capital, may also become a producer of vulnerability. These complex mechanisms are under researched and poorly understood. The post-conflict social topography of Afghanistan has important implications for women that can only be partially addressed with reference to human rights but may be more fully apprehended by taking account of the full complexity of evolving livelihood systems under conditions of precarious stability.

The remainder of this section will be devoted to arguing two central points:

a) Studies adopting more holistic, livelihoods-based approaches are better able to situate the operations of gender in the changing socio-economic realities of Afghanistan.

b) Gender analysis is central both to an understanding of livelihoods and to interventions aimed at enhancing livelihoods.

These arguments will be developed by means of illustrations provided by case studies drawn from the literature and from data obtained during the pilot stage of the UNIFEM study.

\section{Looking "inside" the household}

Households respond to the erosion of their asset bases by diversifying their activities, deploying migrant members who can send remittances, and in extreme cases, resorting to negative coping strategies such as begging or prostitution that may expose their more vulnerable members (women and children) to new forms of exploitation. Food insecure households may send young boys away to work as servants, shepherds or workers. The reluctant marriages of girls as young as seven or eight years old to older men sometimes represent "distress" sales to secure food or cash (Lautze et.al. 2002). New coping strategies may both build upon and destabilize age and gender hierarchies in households. Gender analysis forces us to look at intra-household divisions of labour and to identify the mechanisms that generate social safety nets or contribute to increased insecurity. The case studies below provide some pointers in this respect.

\section{Case 1 Intergenerational shifts in power among men}

\footnotetext{
${ }^{12}$ Bourdieu (1977) makes a useful distinction, in this respect, between the concepts of 'doxa', which refers to unquestioned, self-evident and common sense assumptions about social life and 'orthodoxy' that actively articulates and enforces the boundaries of the permissible. The imposition of 'orthodoxy' generally requires more coercive means. It may be argued that the type of orthodoxy enforced by the Taliban was far from traditional in that it moved the locus of control of women from the household and community to the state and agents of the state, disempowering certain categories of men in the process.
} 
A study of Deh Dehi village in Badakshan (Goodhand, 2000) chronicles the shift from an agricultural economy based on wheat, barley and livestock to poppy cultivation and the opium trade as the mainstay of village economy. Virtually all the irrigated land is given over to poppy cultivation and men who would previously have been involved in the livestock trade are either working in the opium trade or abroad. This trade is monopolized by young men who make the dangerous journey to the Tajik border where the opium finds its way to Central Asian export routes. Their profits are invested in small shops and businesses in Deh Dehi which have multiplied over a period of ten years.

At the village level, the opium economy has transformed social relations through the creation of a new moneyed stratum of young men involved in the opium trade and of commanders taxing and controlling the trade. Although the authority of traditional village leaders seems so far intact, father-son relationships are increasingly coming under strain. Sons who command their own resources from income earned abroad, through the opium trade or through their involvement with local militias are less likely to depend on their fathers, especially in marriage transactions. Neolocal marriages are reported with young men setting up their separate households. The decline of hashar, voluntary communal activity for harvesting or building activities, is also noted.

Although the implications of this study for women are not altogether clear, it raises many important questions. Does the erosion of patriarchy (understood here as the authority of male elders) at village level expose women to new forms of vulnerability or opportunity? What influence do these trends have on the reproduction of village households and on marriage payments? Do kin networks among women keep the less commodified areas village life alive? To what extent do these networks account for the apparent resilience of village social capital?

\section{$\underline{\text { Case } 2}$ Women and children as main breadwinners}

A study based on an evaluation of the Save the Children (US) programme in northern Afghanistan,) in Faryab province shows that successive shocks due to war, displacement and drought, have both increased reliance on carpet production, in the context of lack of viable livelihood alternatives and transformed independent local carpet production into a putting-out system controlled by Peshawar-based traders (Pain, 2001).

Previously, production and marketing systems were small-scale and local, working through a network of Uzbek and Turkmen producers and merchants. Nowadays, ethnic groups that did not traditionally produce carpets have become involved and Pakistanbased traders are exerting increased control. These changes occurred incrementally over a period of time that saw agricultural markets collapsing after the Soviet invasion, the growth of carpet production in Peshawar due to mass displacement, the progressive isolation of Faryab from carpet markets and the downward pressures on livelihood strategies occasioned by drought. 
Whereas previously carpet-weaving was a supplement to household income (which derived from multiple sources), it has now become the primary source for many families, putting women (and children) in the position of primary producers and breadwinners. Weaving households are enmeshed in ties of dependence to traders that reduce them to being piece-workers. Under these circumstances, the role of NGOs that provide looms, materials and basic skills to households may become problematic in that they replicate the role of traders (without necessarily being able to alter unfavourable terms of trade for the producers). They may, however, enhance security through the provision of regular work. The effects of putting women and children into major breadwinning roles in a context where men control the marketing may be far from empowering, although households may have little choice in terms of alternatives. This study shows that gender divisions of labour are subject to transformations that reflect the effects of a complex range of economic and political factors on livelihood systems.

\section{Case 3 Women coping on their own}

This case is illustrated by a household in the Surkhi Parsa district of Parwan (UNIFEM pilot study) headed by a woman who was widowed seven years ago. Her eldest son, who was the only able-bodied man in the family, was killed by the Taliban in Takhar province (occasioning a major financial shock and a debt of 35 lakh Afghanis to pay for his funeral). Her two youngest daughters and son are in an orphanage in Kabul where she hopes they will receive some education. She lives with three unmarried daughters and two sons, one of which is disabled. They have no immediate relatives abroad and receive no remittances. The eldest daughter is 28 and unmarried; she is needed by her mother to work on the land and take care of her younger siblings.

This family works on other people's land as sharecroppers, which occupies them for seven to nine months of the year. They also own a small plot of land (under 1 jerib) which they use for self-subsistence. They have no surplus to sell except for some dried fruits and nuts which they de-shell and market. Women are involved in all stages of agriculture including irrigation, which can take place at any time of day or night depending on the water schedule set by the mirab. This is accepted by the community since they have no male member of the family to perform this operation. The second eldest daughter, who spent two years in Pakistan with her uncle working as a carpet weaver, now works in the village with three other women making carpets which are sold to a Kabul-based trader. She has no loom of her own and it is her uncle who deals with the trader.

This precarious combination of self-subsistence, sharecropping and carpet weaving is based on the full deployment of all available family labour. An unfavourable ratio of workers to dependents could easily push them into destitution. This means that daughters above marriage age are still kept at home and younger children are sent to an orphanage to have fewer mouths to feed.

Case 4 "False" extendedness and the pooling of poverty 
Afghan rural households live in qala (compounds) which commonly shelter multiple families. It is often assumed that these are patrilocally extended families which act as joint production and consumption units. In fact, relatively few households in the UNIFEM pilot study conformed to this ideal type. A closer examination of income pooling and budgeting arrangements revealed a variety of patterns which are indicative of different levels of relative welfare or poverty.

A household in the Sheik Ali district of Parwan province headed by a widowed woman points to the need to explore intra-household budgeting and income-pooling arrangements in greater detail. There are eleven people and two families in this qala. However, they keep two separate cooking pots. Bibi Gulsum cohabits and cooks with a single daughter and one of her daughters-in-law and her three children. Her elder son who migrated to Iran two years ago appears to have deserted his family- he sends no remittances. The abandoned daughter-in-law is not a relative of the family. Her other married son and his wife, with their three children keep a separate cooking pot.

This is a household that owns no land or animals (except for two donkeys). They live in a borrowed house for which they pay no rent. They report a diet consisting almost exclusively of beans, potatoes and mushrooms they occasionally gather (with no meat or green vegetables). They depend on odd jobs and services for which they get paid in kind. Bibi Gulsum makes tablecloths for sale (she received 3,5 kg. of rice, some tea, kerosene for her lamp and some salt for her last order). She also spins wool by hand (earning $1 / 2 \mathrm{ser}$ of wheat per $1 \mathrm{~kg}$. of wool). She does weeding in other people's fields as do her daughter and daughter-in-law who also perform household chores and wash clothes for others, receiving payment in kind. It is clear that there is very little to go around which may have influenced the decision to keep separate cooking pots. Yet, this is also a case where an unrelated daughter-in-law is kept in and sheltered despite desertion and poverty.

\section{Women's "Hidden" Economic Roles}

The cases above demonstrate that changes in the productive activities and/or demographic composition of households may destabilize age and gender hierarchies and the normative expectations related to them. They also reveal a substantial input of female labour into the survival of their families, either as wage workers (in casual agricultural work, carpet weaving and other handicraft production) or as unremunerated family labourers. Despite women's much vaunted immobility in Afghanistan, they are centrally involved in key commodity chains destined for export. Carpet weaving, dried fruit and nut processing and the cultivation of opium poppies are highly reliant on a female work force whose labour has very low opportunity costs. The invisibility of women's involvement may lead not only to misjudgements of their actual contribution but also to gender-blind policy responses. The cases below develop these ideas in relation to women's role in opium poppy cultivation, in embroidery for export and in pastoral activities.

Case 5 Women's role in opium poppy cultivation 
A recent article puts forward the view that high yielding varieties of wheat are likely to supplant opium poppy production in Afghanistan. The main argument put forward is that labour intensive nature of poppy cultivation makes it less profitable. ${ }^{13}$

A detailed series of studies (Mansfield, 2001a, 2001b ) suggest that analyses based on economic rationalist concepts of profit maximizing farmers may fall short of capturing the complex ways in which poppy growing is integrated into the livelihood and survival strategies of different socio-economic groups. For the vast majority of poorer households, such as the landless and poor sharecroppers, their only access to land, credit and inputs goes through opium poppy cultivation which also allows them to deploy the only asset they have-namely unpaid family labour.

A study conducted by the UNDCP Afghanistan Programme (2000) on women's role in opium poppy cultivation was based on fieldwork conducted in northern and eastern poppy growing regions. Although it makes no claims to a comprehensive gender analysis, the study clearly demonstrates that women play an important role in the cultivation of opium poppy. They participate in all stages of production including the provision of food for hired or reciprocal (ashar) labour. Despite some regional variations in the type and extent of women's participation (women being more active in harvesting operations in the north) households with limited human and financial capacity deploy women's labour at all stages of the production process.

One of the central premises of this study is that the low opportunity cost of women's labour, whose income generation alternatives are severely restricted, makes opium poppy cultivation a more attractive option for households. Any alternative development intervention aimed at reducing drug crop cultivation would necessarily have to take account of the possibilities and limitations of women's off farm and non-farm activities. The study recommends a comprehensive gender analysis, especially in southern Afghanistan where the paucity of information about gender roles is particularly acute.

\section{Case 6 Middle-women, embroiderers and shop-keepers}

It is often assumed that women themselves are seldom involved in trade and that their only access to the market is mediated by male relatives and merchants. Two middlewomen, interviewed in the course of the UNFEM pilot project, show that women themselves may act as intermediaries between house-bound women embroiderers and shopkeepers in Kandahar city who export embroideries to Pakistan. They play key roles in a putting-out system that offers income-earning opportunities to village-based women.

Koko Gul , from the Suleimankhel tribe, was widowed three years ago when her husband died after a long illness. The cost of his treatment and of the funeral got her into debt. Previously, she helped her husband who owned an embroidery shop by travelling to

\footnotetext{
13 'Given a reliable water supply economics favour wheat. For an average field of one fifth of a hectare wheat requires 25 to 30 days of labour and yields $\$ 100$ to $\$ 200$ profit, the same field planted in poppies requires 300 to 400 days of labour and yields $\$ 1000$ to $\$ 2000$ profit. (Lawton, 2002, p. 18)
} 
surrounding villages (accompanied by her young son) to collect embroideries. After her husband's death, she lost the shop due to her debts and now works for other shopkeepers.

Koko Gul deals with about 500 women workers in two districts and works for three to four traders. The villages she visits are two hours' drive away by bus. About four years ago, she started being accompanied by Shah Gul, who is married but impoverished because her elderly husband is unable to work.

The shopkeepers provide cloth and thread for the women workers. Koko Gul goes to villages at least three times per month: to bring material, for quality control and to collect the finished products and pay the workers. Although she is illiterate, she uses a notebook and a system of notation using vertical bars which she crosses. Her knowledge of the Arabic script through the Quran helps her to recognize the denominations on the banknotes. During the rest of the month, she prepares the material for delivery by washing and ironing the embroidered pieces.

Koko Gul says that she is happy with the profits she makes and with her working conditions. She earns 500 Pakistani Rupees (about US\$ 9) and some sugar and tea per piece of embroidered material. She can collect between 4 to 20 pieces of embroidery in one month and thus, during a good month, she can earn about US\$180. The workers earn up to 2,000 Pakistani rupees (US\$ 39) for a good piece of work. The shopkeepers sell a quality piece of embroidery for between US\$50 to 100 .

Probed further on her conditions of work, she admits that it would be better to have her own business and "to be independent". She feels, moreover, that she is not in a good bargaining position with respect to changing her conditions since traders can easily find others to replace her. There are other women doing the same job (she knows about thirty of them) and there is competition between them. Extra money is even offered to workers to incite them to speed up or to improve the quality of their work.

Several factors helped Koko Gul to find a niche as a middle-woman. She was already familiar with the work through her involvement in her husbands' business, had established networks among village-based embroiderers and was known to a number of shopkeepers. She is also an older, widowed woman whose mobility is better tolerated and who is freed of domestic duties by her daughter-in-law. There are, nonetheless, downward pressures on her earnings due to an apparently abundant supply of women competing for the same niche. Her prospects for accessing credit or setting up her independent business are non-existent.

\section{Case 7 Women's pastoral activities}

Although women's involvement in tending livestock, milking and processing dairy and wool products is generally acknowledged, the extent of their input is not widely recognized. In the Panjsheer district of Parwan provice, women are involved in aghel 
(summer pasturing) during three months of spring/summer when they go to the hills to tend animals and to produce dairy products. They are unaccompanied except by a shepherd who takes the animals to pasture and sometimes report having to carry guns to protect their animals from wolves. These dairying activities constitute a significant contribution to their households.

Aziz ul-Nissa has been going to aghel for the past nine years and has taken care of 50 animals (cows, sheep and goats) during the previous season. She owns about 15 of these animals and the rest belong to her neighbours. Her husband, who is too old to work, allows her to take on this responsibility.

Works is extremely hard during the aghel period. She milks the animals between 3:00-to 6:00 a.m. She then cleans the pots and boils the milk. She makes yoghurt which she churns to produce butter. She then produces qurut (a dry cheese). Between 12:00-1:00 the shepherd takes the animals to pasture. He receives 10 lakh Afghanis for his services over three months. After 4:00 p.m., the animals are milked again and the preparation of yoghurt, butter and qurut resumes. She pays back 2 or 3 cans of oil (each can is 2,5 ser) to the people whose animals she takes to aghel.

However few, the data points at our disposal suggest that any facile generalizations concerning women's actual or potential contributions should be actively discouraged in favour of adequate research and documentation.

\section{The nexus of gender and class: the dilemmas of social reproduction}

If women's productive activities receive little attention, their roles in the social reproduction of their families and communities is even less recognized. The domestic economy depends not only on productive and reproductive activities but on a complex nexus of gift exchanges and ceremonial outlays that cement kinship networks and are central to building the social capital that binds communities together. Interviews conducted in Parwan province suggest that one of the most important categories of expenditure (which constitute important financial shocks often leading to indebtedness) relate to staging life-cycle ceremonies. Marriage payments and wedding and funeral costs constitute an important source of inter-household transfers, the scale and impact of which is difficult to estimate.

Some inter-household transfers may have redistributive effects. Largesse usually flows from higher status members of the community to their poorer relatives and neighbours. ${ }^{14}$ Processes of social differentiation, leading to greater disparities of wealth, often result in the poorest and those least able to reciprocate losing access to the social safety net provided by kinship and community ties. Women, just like men, do not constitute a homogenous category and their interests and opportunities are closely tied in to the social strata they belong to. Greater mobility and economic activity among poorer women may

\footnotetext{
${ }^{14}$ For instance, a debt of $\$ 2000$ was reported in a household in the Charikar district of Parwan for the funeral of the head of household. During a period of forty days, the inhabitants of the village were fed at week-ends on a high protein diet of meat and rice.
} 
be achieved at the expense of social status in communities where women's confinement to domestic space is a mark of wealth and distinction. Some interventions may have unintended effects if the nexus of class and gender in Afghanistan is poorly understood. The case study below illustrates this point quite clearly.

\section{Case 8 A perplexing tale of rural water supply}

This case is based on an evaluation study of the use of wells provided by DACAAR in three villages in Laghman, Nangarhar and Herat. Its purpose was to understand "unexpected patterns of behaviour" in the communities that benefited from water supply interventions (Klijn, 2002). The deceptively simple aim of uncovering the reasons why certain wells fall into disuse while others are utilized uncovers complex village-level dynamics where the operations of both socio-economic stratification and gender are clearly evident.

On the one hand, access to water is mediated by land ownership patterns whereby wealthy landowners provide water or the means to obtain it to poorer families who are their clients. (The labour obligations of poorer families to the rich flowing from access to water are often negotiated among the women since poorer women are the traditional water collectors and are allowed to enter the compound of another family). On the other hand, village space is strongly gendered leading to a process of constant negotiation over the use of public spaces, including sanctioned water sources.

Considerations of social status related to wealth strongly influence appropriate gendered conduct (in wealthier families it is men and boys who collect water while among the poorer strata it is considered shameful for a man to collect water). The installation of new wells opens up an arena of negotiation between differently positioned social groups (men and women, the rich and poor) who may invoke gender-appropriate behaviour to justify their use or avoidance of certain water sources.

Among returnees from Iran in Herat both the convenience of private sources and the tightening of hijab (as compared to pre-emigration village patterns) seem to have stimulated the privatization of water sources and an increase in digging of private wells. The installation of public wells by assistance agencies not only raises self-consciousness about gender-appropriate conduct but has, in some instances, contributed to the tightening of gender segregation.

One of the important conclusions of this study is that rules of gender segregation are dynamic. They respond to changing circumstances and are subject to varying interpretations of gender-appropriate behaviour that may be mobilized by different players to make new situations acceptable or otherwise. ${ }^{15}$

\footnotetext{
${ }^{15}$ Thus, the desirability of keeping women within the compound may be invoked as the overt rationale for digging a private well by a former retainer household that is, in fact, trying to opt out of relations of dependency to the landlord. In another instance, women may return to collecting water from the landlord's well (as in the case when the DACAAR well fell into disuse) on the grounds that going to the village stream would expose them to unrelated men.
} 
Despite the scarcity of primary data, already alluded to in Part 1, the studies presented above make a strong case for combining a livelihoods perspective with gender analysis to generate policy-relevant information for the social and economic empowerment of women. The final section of the report addresses the means used to achieve this objective.

\section{Part 3: Ways Forward: A Multi-Focal Study}

\section{The Context}

The proposals made above must be set in the context of a number of encouraging developments that create demand for the integration of gender analysis into livelihoods frameworks. There are important synergies between the goals pursued by the UNIFEM study and a number of current initiatives:

- The Ministry of Rural Rehabilitation and Development (MRRD) is developing a Food Security and Nutritional Surveillance System with input from the Ministry of Public Health (MOPH) and the Ministry of Agriculture (MOA). The aim is to protect and support food security and nutrition of most vulnerable communities through the collection, analysis and use of information, using a livelihoods framework for analysis. This will lead to in-depth assessments using qualitative and quantitative data at the district and village levels.

- The Afghan Research and Evaluation Unit (AREU) is conducting an EC-funded project whose overall objective is to contribute to 'the empowerment of Afghans, both men and women, to build sustainable livelihoods'. This is the first phase of a planned three-year project that will focus on rural livelihoods.

- WFP VAM (Vulnerability Assessment Mapping) units and the FAO have a long track record of work in complementary areas and have contributed to both data bases and capacity building.

\section{Design of the Study}

The UNIFEM study aims to achieve an optimal level of co-ordination and co-operation with ongoing efforts in government, $\mathrm{UN}$ and other agencies in order to make the best use of existing research capacity and to contribute to building expertise in gender analysis. The design of the study reflects this goal and is based on the premise that a combination of qualitative, quantitative and case study methodologies are best suited to the objectives of the project. It consists of three components:

- Qualitative (pilot) study

- Special studies

- Quantitative study 


\section{The Pilot Study ${ }^{16}$}

The purpose of the pilot study was to test a range of qualitative tools developed after exploratory site visits to Parwan and Kandahar provinces.

An annotated field guide was prepared consisting of four schedules:

- Community profiles

- Household Profiles

- Co-resident Women's Profiles

- Case Studies

(See Appendix)

The primary aim of this phase was exploratory. Some of its most salient conclusions concerning the place of gender analysis in livelihoods research are reflected in Part 2 above.

\section{Special Studies}

The aim of special studies is to focus specifically a) on contexts that are generate vulnerability and b) contexts that support and encourage women's leadership roles. There are a number of ongoing projects that target both vulnerable groups and support women's leadership roles. These offer an appropriate context for special studies:

- WPF Women's Bakeries in Kabul: This is project assists 350 vulnerable families (many of them widow-headed) and employs 24 supervisors (many of which have higher education degrees).

- The CARE Kabul Widows Humanitarian Assistance (KWHA) programme currently serves approximately 8,500 widows and their families.

- The UN Habitat Community Forum Programme has been running Women's Community Forums in many districts. These feature a variety of community enterprises alongside health and education services. Although Women's Forums have not been the subject of a separate evaluation (see Rodey, 2000 for a general evaluation) they offer a potential resource for the study of women's community leadership roles and their impact on the sustainability of community enterprises.

\footnotetext{
${ }^{16}$ The pilot study was carried out between 26 September-18 November 2002 . The data obtained during this phase consisted of 3 community profiles, 17 household profiles, 2 women's profiles and three "women gatekeeper" profiles. The research sites were in Parwan province ( districts of Charikar, Surkhi Parsa, Sheikh Ali, Ghorband and Panjsheer), Kandahar city and Helmand.
} 
The proposed data collection methods include both socio-demographic profiling and indepth interviewing and case study techniques.

\section{Quantitative Study}

The purpose of the quantitative study is to broaden the scope of selected research sites to allow for a wider diversity of livelihood contexts and to develop a questionnaire (based on the findings of the pilot study) that can be subjected to quantitative analysis.

Possibilities of site-based collaboration with the EC-funded AREU project on rural livelihoods are currently under discussion. Such collaboration would have the following advantages:

- Avoiding duplication of effort in site selection and sample design

- Creating synergies in capacity building for local research staff

- Streamlining the research tools of the UNIFEM study to focus on a more narrowly targeted range of issues. ${ }^{17}$

- Facilitating quality control and data analysis.

\section{Time Frame and Outputs}

The UNIFEM study requires the following steps:

- Selection and training of Kabul-based UNIFEM research co-ordinator

- Sampling and development of research tools for Special Studies

- Questionnaire design for Quantitative Study

- Sampling and interviewer training for Quantitative Study

- Data analysis and production of report for Special Studies

- Quality control, coding, data entry and data processing for Quantitative Study

- Presentation of consolidated final report based on the findings of the three components of the research design

The Special Studies and Quantitative Study are not designed to be sequential. The fact that Special Studies will be carried out in urban sites and the Quantitative Study will take

\footnotetext{
${ }^{17}$ The pilot study utilized four schedules (see above). The first two duplicate the areas that are covered by the AREU rural livelihoods study. This was useful and necessary at the exploratory stage of the UNIFEM study but would be wasteful at a more advanced stage. The AREU project could provide background data on the communities surveyed and might permit a selective sub-sampling of households for gender analysis. This would facilitate purposive sampling based on already known household characteristics. This, in turn, would benefit the AREU project by adding a gender component to livelihoods analysis.
} 
place in rural areas introduces a necessary element of diversity to the UNIFEM data set. It is envisaged that the data collection, processing and analysis process for both components of the study will take place between April 2003-January 2004. The consolidated final report will be presented in March 2004.

The principal output of the UNIFEM study will be to generate tools and findings that facilitate the incorporation of gender analysis into programmes and projects that have livelihoods enhancement and economic empowerment as their aim. The UNIFEM study can assist:

- UN, bilateral and multilateral funding agencies in the areas of gender analysis and gender training

- the research and advocacy capacity of MOWA

- mainstreaming gender into ongoing livelihoods enhancement and monitoring projects

- local and international NGOs in designing gender-aware projects

- training local researchers and NGO personnel 


\section{REFERENCES}

Abu-Lughod, L. (2002), 'Do Muslim women really need saving? Anthropological reflections on cultural relativism and its others', American Anthropologist, Vol. 104, No. 3, pp. 1-8.

Afghan Ministry of Health, UNICEF and CDC (2002) 'Maternal Mortality in Afghanistan: Magnitude, Causes, Risk Factors and Preventability' 6 November.

Arat-Koc, S. ( 2002), "Imperial Wars or benevolent interventions? Reflections on "global feminism" post September $11^{\text {th }}$, Atlantis (mimeo.)

Azerbaijani-Moghadam, S. (2001), 'Report on Interviews with Returnee Women and Girls in Heart Province, Afghanistan', Women's Commission for Refugee Women and Children.

(2002), 'Afghanistan Gender Guidelines', Report of the EC Rapid Reaction

Mechanism Assessment Mission, European Commission

Barakat, S. and Wardell, G. (2001), 'Capitalizing on the Capacities of Afghan Women: Women's Role in Afghanistan's Reconstruction and Development', InFocus Programme on Crisis Response and Reconstruction, Working Paper 4, Geneva: ILO.

Bhatia, M. and Goodhand, J. with Atmar, H., Pain, A. and Suleman, M. (2002), 'Profits and Poverty: Aid, Livelihoods and Conflict in Afghanistan' (mimeo.)

Benjamin, J., (2002) 'Post-Taliban Afghanistan : Changed Prospects for Women?', February, UN Coordinator's Office, Afghanistan.

Burnet, A. and Solon Helal, I. , (2002) “Women's Rights in Afghanistan” Report of Rights and Democracy Mission to Afghanistan, September.

William Byrd (2002) “Afghanistan's Reconstruction: Regional and Country Context-A Discussion Paper" October 31.

Centlivres-Demont, M. (1994) 'Afghan women in peace, war and exile' in Weiner, M. and Banuazizi, A. (eds.) The Politics of social transformation in Afghanistan, Iran and Pakistan, Syracuse, NY: Syracuse University Press.

Chant, S. and Guttman, M. (2000) Mainstreaming Men into Gender and Development Oxford: Oxfam.

Christensen, H. (1984), 'Afghan Refugees in Pakistan: From Emergency Towards Self-Reliance - A Report on the Food Relief Situation and Related Socio-economic Aspects', Report No. 84.2, Geneva: UNRISD

(1988) 'Survey of the Social and Economic Conditions of the Afghan Refugees in Pakistan', Report No. 88.1, Geneva: UNRISD.

UNRISD.

(1990), 'The Reconstruction of Afghanistan - A Chance for Rural Afghan Women', 
Clarke, P. and Seeman, J. (1998) 'A Preliminary Guide to the Food Economies of Afghanistan. WFP VAM Project. World Food Programme, Islamabad.

Cornwall, A. (2000) 'Missing Men? Reflections on Men, Masculinities and Gender in GAD' IDS Bulletin, Vol. 31, No.2,pp.

Cramer, C. and Goodhand, J. (2002) 'Try Again, Fail Again, Fail Better? War, the State, and the 'Post-Conflict' Challenge in Afghanistan' Development and Change, 33 (5), pp.885-909.

Cockburn, C. (1998) The Spaces Between Us: Negotiating Gender and National Identities in Conflict London: Zed Books.

Dupree, N. Hatch (1984) 'Revolutionary rhetoric and Afghan women ' in Shahrani, N. and Canfield, R. (eds.) Revolutions and rebellions in Afghanistan, Berkeley: University of California Press.

(1998), 'Afghan Women Under the Taliban', in Ed. W. Maley, Fundamentalism Reborn? Afghanistan and the Taliban, London: Hurst.

Food and Agriculture Organization (1997), 'Gender and participation in agricultural development planning: lessons from Afghanistan', Women in Development Service, FAO.

Gardner, A. and Mohamed, A. Salih, (2002) 'Results of a Nutrition Survey and Program Evaluation', Humanitarian Assistance for Women of Afghanistan (HAWA), CARE International in Afghanistan.

Goodhand, J. (2000) "From holy war to opium war? A case study of the opium economy in North Eastern Afghanistan “Central Asian Survey 19, 2, pp.265-280.

Grima, B. (1992) The Peformance of Emotion among Paxtun Women, Austin: University of Texas Press.

Howard-Merriam, K. (1987), 'Afghan Refugee Women and their Struggle for Survival', in Farr, G and Merriam, J. (eds.), Afghan Resistance: the Politics of Survival, London: Westview Press.

Human Rights Watch, (2001) 'Humanity Denied: Systematic Violations of Women's Rights in Afghanistan', Human Rights Watch, Vol. 13, No. 5, October.

Human Rights Watch, (2002) 'Taking Cover: Women in Post-Taliban Afghanistan', Human Rights Watch Briefing Paper, May.

Jacobs, S. et.al. (2000) States of Violence: Gender Violence and Resistance London: Zed Books.

Kandiyoti, D. (1991) Women, Islam and the State, London: Macmillan.

(1993 ) "Identity and Its Discontents: Women and the Nation" in L. Chisman and P. Williams (eds ) Colonial Discourse and Post-Colonial Theory, Harvester Wheatsheaf.

Klijn, F. ( 2002), 'Water Supply and Water Collection Patterns in Rural Afghanistan - An Anthropological Study', Peshawar: DACAAR.

Lautze, S., Stites, E., Noujmi, N. and Najimi, F. (2002) Qaht-e Pool “A Cash Famine” Food Insecurity in Afghanistan 1999-2002.

Lawton, J. (2002) 'Rebuilding in Afghanistan' Saudi Aramco World November/December. 
Mansfield, D. (2001a), 'Alternative Development in Afghanistan: The Failure of Quid Pro Quo', Prepared for the International Conference on Alternative Development in Drug Control and Development Cooperation, Feldafing, September 17, 2001.

-D. (2001b) The Economic Superiority of Illicit Drug Production: Myth and Reality’ Paper prepared for the International Conference on Alternative Development in Drug Control and Development Cooperation, Feldafing, January, 2002.

Marsden, P. (1999), The Taliban: War, Religion and the New Order in Afghanistan, OUP, Karachi.

Moghadam, V. (2002), 'Patriarchy, the Taleban and Politics of Public Space in Afghanistan', Women's Studies International Forum, Vol. 25, No. 1, pp. 19-3.

Moser, C. and Clark, F. (eds.) (2001) Victims, Perpetrators or Actors? Gender, Armed Conflict and Political Violence London: Zed Books.

Pain, A. (2001), 'Livelihood under stress in Faryab Province, Northern Afghanistan - Opportunities for support', Save the Children U.S., Pakistan/Afghanistan Field Office.

--------(2002), 'Understanding and Monitoring Livelihoods Under Conditions of Chronic Conflict: Lessons -From Afghanistan', September 4. Afghanistan Research and Evaluation Unit (AREU).

Pain, A. and Goodhand, J. (2002), 'Afghanistan: Current employment and socio-economic situation and prospects', InFocus Programme on Crisis Response and Reconstruction, Working Paper 8, Geneva: ILO.

Pain, A. and Lautze, S. (2002) 'Livelihoods in Afghanistan', Afghanistan Research and Evaluation Unit (AREU), August 29.

Physicians for Human Rights, (2002) 'Maternal Mortality in Heart Province, Afghanistan - An Index of the Status of Women's Rights', July 26.

Pont, A. (2001), Blind Chickens and Social Animals - Creating Spaces for Afghan Women's Narratives Under the Taliban, Portland, OR: Mercy Corps.

Povey, E.R. (forthcoming) 'Women in Afghanistan: passive victims of the Borga or active social participants? Development in Practice.

Rodey, B. J. ( 2002), '"Quantum Leap...” A Framework for Peace and Development in Conflict and Post-Conflict Afghanistan: A Socio-Economic Evaluation of the Community Forum Programme', UNHCS Habitat.

Rehn, E. and Johnson Sirleaf, E. (2002) 'Women, War and Peace. The Independent Experts' Assessment on the Impact of Armed Conflict on Women and Women's Role in Peace-building" UNIFEM.

Roy, O. (1985) Islam and Resistance in Afghanistan. Cambridge: Cambridge University Press.

Rubin, B. (1995) The Search for Peace in Afghanistan. From Buffer Sate to Failed State. New Jersey $\mathrm{CT}$ and London: Yale University Press.

(1996) The Fragmentation of Afghanistan State Formation and Collapse in the International System. Lahore: Vanguard Books. 
-(2000), 'The Political Economy of War and Peace in Afghanistan', World Development, Vol. 28, No. 10, pp. 1789-1803.

Tapper, N. (1991), Bartered Brides: Politics, Gender and Marriage in an Afghan Tribal Society, Cambridge: Cambridge University Press.

Toynbee, P. (2002) 'Was it Worth It?’ The Guardian, G2, November 13.

UNDCP (June 2000), 'The Role of Women in Opium Poppy Cultivation in Afghanistan', Strategic Study \#6.

Viner, K. (2002) 'Feminism as Imperialism' The Guardian, September 21.

Wimmer, A. and Schetter, C, (2002), 'State-Formation First. Recommendations for Reconstruction and Peace-Making in Afghanistan’, April, ZEF Discussion Papers on Development Policy \#45, Bonn.

WOMANKIND Worldwide, (2002) 'Taking Stock: Afghan Women and Girls Six Months On', July, 3 . 


\section{APPENDIX \\ Socio-economic needs assessment- Annotated field guide}

Schedule 1

\section{COMMUNITY PROFILE}

(This information is obtained through key informant interviews with community leaders such as heads of the local shura or heads of administration.)

\section{History of settlement:}

This covers stories of origin, main tribal/family/ethnic groups in the village, impact of conflict on the settlement including displacement and modifications in property holdings.

2. Current composition of population:

Size of settlement, proportion of IDS and returnees, main groups in the village.

\section{Infrastructure:}

Road connections, distance of nearest market, school and health facility. Availability of irrigation and potable water. Sources of fuel and energy for cooking and heating.

4. Main economic activities:

Land use and distribution (crops and size of holdings), labour patterns (sharecropping, leasing, casual labour), animal husbandry, trade, handicraft and other production and service activities.

5. Assistance profile

Extent of presence of $U N$ or NGO relief programmes and activities. 


\section{Schedule 2}

\section{HOUSEHOLD PROFILE}

(This information is obtained from the person -male or female-designated as head of household)

\section{Length of residence/migration-return history}

2. Household composition:

Lead question- How many khana do you have in this qala? Are there members of your family living elsewhere?

Attempt diagram of family structure including both members of co-resident families and members residing elsewhere in Afghanistan or abroad.

Do you keep separate or joint budgets/kitchens? Since when? Why?

(The aim is to ascertain what adjustments are being made to changing economic circumstances and how this is reflected in household budgeting).

3. Household assets:

Land (in the village or elsewhere)

Animals

Machinery (tools, looms, transport vehicles)

Other (shop or other sales trade facility)

Household durables

(In rural areas)

Sewing machine

Radio

(add as necessary in urban areas)

For this question attempt a time line going back to the dates indicated in question 1. The aim is to ascertain the extent of asset depletion or otherwise.

\section{Main sources of livelihood}

Land- crops cultivated, degree of self-subsistence achieved, crops sold on the market Animals and sale of related produce

Remittances

Casual labour

Salaries

Trade

Other 
In rural areas seasonal cycles and gender/age divisions of labour may be ascertained by using charts (Month of the year, crop, activity (soil preparation, planting, weeding, harvesting, post-harvest processing). Those responsible for each operation are noted.

\section{Financial shocks:}

Lead question: What has been the heaviest expenditure your family has experienced during the last year?

There may be a variety of responses such as:

\section{House construction}

Health care for a sick member

Financing a life cycle ceremony (a wedding or a funeral)

Raising money for travel abroad

Investing in a trade venture

Other

Note any combinations of these and go back in time to the previous year until you hit a significant expense.

\section{Debt/credit}

Lead question: Were you able to meet these expense through your own means or did you need to borrow? If yes, who from? (It would be good to have an indication of the scale of debt but do not press if information not volunteered).

Has you family extended credit to relatives or others? 


\section{Schedule 3}

\section{CO-RESIDENT WOMEN'S PROFILES}

(This schedule may be used flexibly as a group discussion with all co-resident women present at the time.)

1. Number of married/widowed women in household

This questions acts as an opener and a check on the household diagram in schedule 2.

Use the chart to list each woman and the number of children she has.

2. Type of marriage (monogamous/polygynous; exchange marriage; marriage with close relative, distant relative, outsider-begana)

Type of marriage payment: brideprice, mahr, exchange

3. Basic skills profile:(for each woman present)

Literacy

Sewing/tailoring

Embroidery

Weaving

Other

4. Domestic divisions of labour:

Lead question: What is the heaviest work for you in this house?

(identify problems such as non-availability of water or fuel, lack of soap/detergent etc)

Who decides how the work will be organized? Who does what?

Cooking

Making bread

Washing

Cleaning

Collection of fuel

Fetching water

Preparing fuel

Looking after children

5. Unpaid farm-related activities

Milking

Tending sick animals

Feeding/pasturing

Poultry

Weeding

Harvesting

Cooking for hired labour

Post-harvest processing (drying fruit, de-husking wheat etc.)

6. Paid activities (in cash or in kind)

Work on others' land

Barter or sale of animal produce

Domestic work for others 


\section{Begging}

Other

This list may change according to context and the purpose is to explore the variety of activities and add to the list.

\section{Decision-making}

Who decides what food will be cooked?

Who decides if a sick child needs to go the doctor?

The purpose is to initiate a discussion of how daily decisions are arrived at in this particular household.

\section{Budget control:}

Lead question: Who keeps the money in this household?

When do you need to ask for money? What for?

Explore participation of women in networks of visiting, gift giving and mutual obligations. 
Schedule 4

\section{CASE STUDIES}

In the course of your work in different communities you will come across women who perform different roles and take on responsibilities that mark them out as community leaders or entrepreneurs. In some contexts these may be traditional midwives and healers who women seek out for advice, in others they may be middle-women organizing a putting out system with women and girls in the production of crafts, in yet others they may be members of elite families or NGO or relief workers who have earned respect. A life narrative method should be used for these case studies. The aim is to explore the local bases of women's authority, prestige or power.

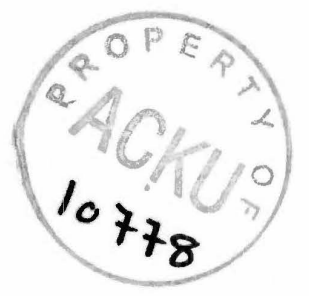

